ISSN 1420-3049

www.mdpi.com/journal/molecules

Review

\title{
Photochemical Oxidative Cyclisation of Stilbenes and Stilbenoids-The Mallory-Reaction
}

\section{Kåre B. Jørgensen}

Department of Mathematics and Natural Science, Faculty of Science and Technology, University of Stavanger, N4036 Stavanger, Norway; E-Mail: kare.b.jorgensen@uis.no

Received: 2 April 2010; in revised form: 21 May 2010 / Accepted: 9 June 2010 /

Published: 14 June 2010

\begin{abstract}
After Mallory described in 1964 the use of iodine as catalyst for the photochemical cyclisation of stilbenes, this reaction has proven its effectiveness in the synthesis of phenanthrenes, other PAHs and phenacenes with a surprisingly large selection of substituents. The "early age" of the reaction was reviewed by Mallory in 1984in a huge chapter in the Organic Reactions series, but the development has continued. Alternative conditions accommodate more sensitive substituents, and isomers can be favoured by sacrificial substituents. Herein the further developments and applications of this reaction after 1984 are discussed and summarized.
\end{abstract}

Keywords: Mallory-reaction; oxidative photocyclization; stilbene; iodine; photochemistry

\section{Introduction}

The oxidative photocyclizations of stilbenes was discovered earlier during studies of the photochemical isomerization of stilbenes [1,2], but the reaction did not become feasible as a synthetic tool until Mallory discovered in 1964 that iodine could catalyze the reaction [3,4]. That allowed for more concentrated solutions and fewer side reactions. The reaction was thoroughly reviewed by Mallory in a large chapter in Organic Reactions in 1984 [5]. Other reviews [6-10] discuss various aspects and applications of the reaction. This review will focus on the reaction as a useful tool in synthesis, covering developments reported since 1984. 


\section{Oxidative Photocyclization}

The reaction pathway of what should be called the Mallory-reaction is pictured in Scheme 1 . Photochemical isomerization of the double bond in stilbene has been extensively studied [8,11]. From a synthetic point of view the cis/trans-isomerization occurs rapidly under the reaction conditions in such a way that different compositions of cis- and trans-stilbenes still give the same products. Thus, the stilbenes can be used as isomeric mixtures in the photocyclization, although only the cis-isomer is capable of the further cyclization. The formed dihydrophenanthrene is unstable and will, unless trapped, relax back to the stilbene. There are also examples of hydrogen-shifts at this stage under nonoxidative conditions [5]. The dihydrophenanthrene can be trapped by oxidation to form a phenanthrene, or by elimination given a suitable substituent in the ortho-position on one of the aromatics.

Scheme 1. Reaction pathways for the photocyclization of stilbenes.

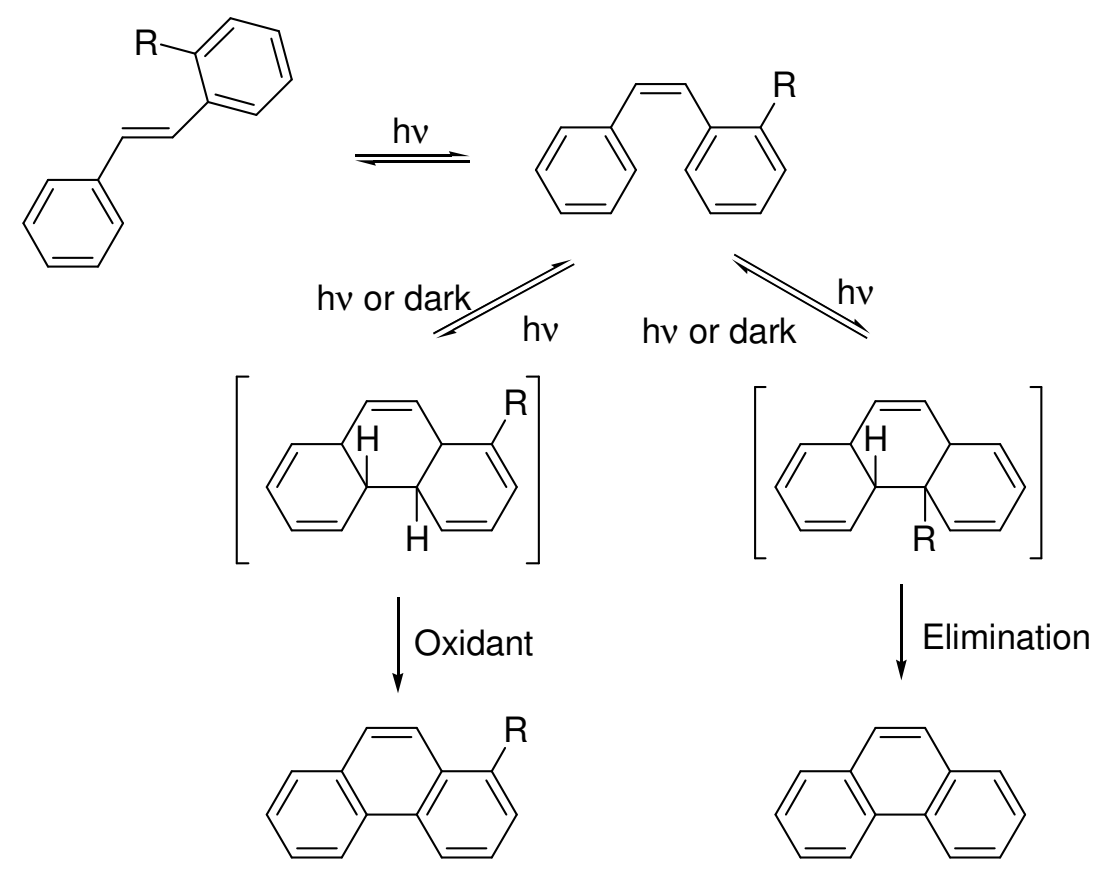

In more concentrated solutions the stilbenes can form dimers in a $[2+2]$ cycloaddition as well $[5,8,12]$. Mallory discovered that this oxidative trapping occurs much faster when traces of iodine were used together with $\mathrm{O}_{2}$ [3], but increased concentrations of iodine did not affect the reaction rate. It has been proposed [5] that iodine is photochemically cleaved into radicals that react in a chain reaction:

$\begin{array}{lllll}\text { Initiation: } & \mathrm{I}_{2}+\mathrm{hv} \longrightarrow \mathrm{I}^{\cdot}+\mathrm{I}^{\cdot} \\ \text { Propagation: } & \mathrm{PH}_{2}+\mathrm{I}^{\cdot} \longrightarrow \mathrm{PH}^{\cdot}+\mathrm{HI} \\ & \mathrm{PH}^{\cdot}+\mathrm{I}_{2} \longrightarrow \mathrm{P}+\mathrm{HI}+\mathrm{I}^{\cdot} \\ \mathrm{PH}_{2}+\mathrm{I}_{2} \longrightarrow \mathrm{P}+2 \mathrm{HI}\end{array}$


The hydrogen iodide is then oxidized back to iodine by oxygen. The reaction was compatible with fluoro, chloro, bromo, methoxy, methyl, trifluoromethyl, phenyl and carboxyl, but not nitro, acetyl or dimethylamino substituents. Iodo substituents were lost during the reaction. Concentrations were usually 0.01 mole/liter of stilbene [4]. Higher concentrations lead to more [2+2] cycloaddition between two stilbenes. The concentration of iodine can influence both product yields and product selectivity. A full equivalent of iodine per cyclization can prevent elimination of methanol [13] (Scheme 2).

Scheme 2. More iodine can prevent eliminative cyclization [13].<smiles>COc1cc(/C=C\c2cccc(/C=C\c3cc(OC)c(OC)c(OC)c3)c2OC)cc(OC)c1OC</smiles><smiles>COc1cc(/C=C\c2cccc(/C=C\c3cc(OC)c(OC)c(OC)c3)c2OC)cc(OC)c1OC</smiles>

$\downarrow h v, \mathrm{I}_{2}$ $\downarrow h v, \mathrm{I}_{2}$<smiles></smiles>

$\underline{\mathbf{a}}$<smiles>COc1cc2ccc3c(ccc4ccc5cc(OC)c(OC)c(OC)c5c43)c2c(OC)c1OC</smiles>

$\underline{\mathbf{b}}$

\begin{tabular}{clc} 
Conditions: & $\underline{\mathbf{a}: \underline{\mathbf{b}}}$ & Yield: \\
\hline 1 eq. $\mathrm{I}_{2}$ & $50: 50$ & 53 \\
2 eq. $\mathrm{I}_{2}$ & $97: 3$ & 35
\end{tabular}

On the other hand, the increased iodine concentration leads to formation of more hydrogen iodide that can saturate the starting stilbene and also contribute to other side reactions [14]. Other oxidants besides iodine have also been used, as reviewed by Laarhoven [10], but do not appear to have been preferred for carrying out syntheses. Representative examples of the Mallory-reaction published after 1984 are shown in Appendix I.

\section{Katz's Conditions}

Although increased amounts of iodine result in better yields in some systems, the increased concentration of hydrogen iodide causes side-reactions that limit the yields. Katz's group officially introduced new conditions in 1991 [14] to solve this problem by scavenging the formed hydrogen iodide with methyloxirane to prevent the side-reactions (they published the first reactions with methyloxirane as a scavenger in $1986[15,16])$. As a consequence the iodide could not be reoxidized by oxygen, so one equivalent of iodine was needed and the reaction could then be performed under an 
inert atmosphere preventing side reactions with oxygen. The combination of hydrogen iodide and light can reduce the double bond in stilbene to a saturated bond [14]. It was observed from the beginning $[3,4]$ that catalytic amounts of iodine gave purer products and higher yields for many systems. It is not oxygen itself that is the destructive agent, but rather substances formed from oxygen during the photocyclization [14]. Table 1 compares the yields between the use of catalytic amounts of iodine and the Katz-conditions.

Table 1. Comparison between catalytic iodine/oxygen and Katz's conditions. Most examples are from ref [14].

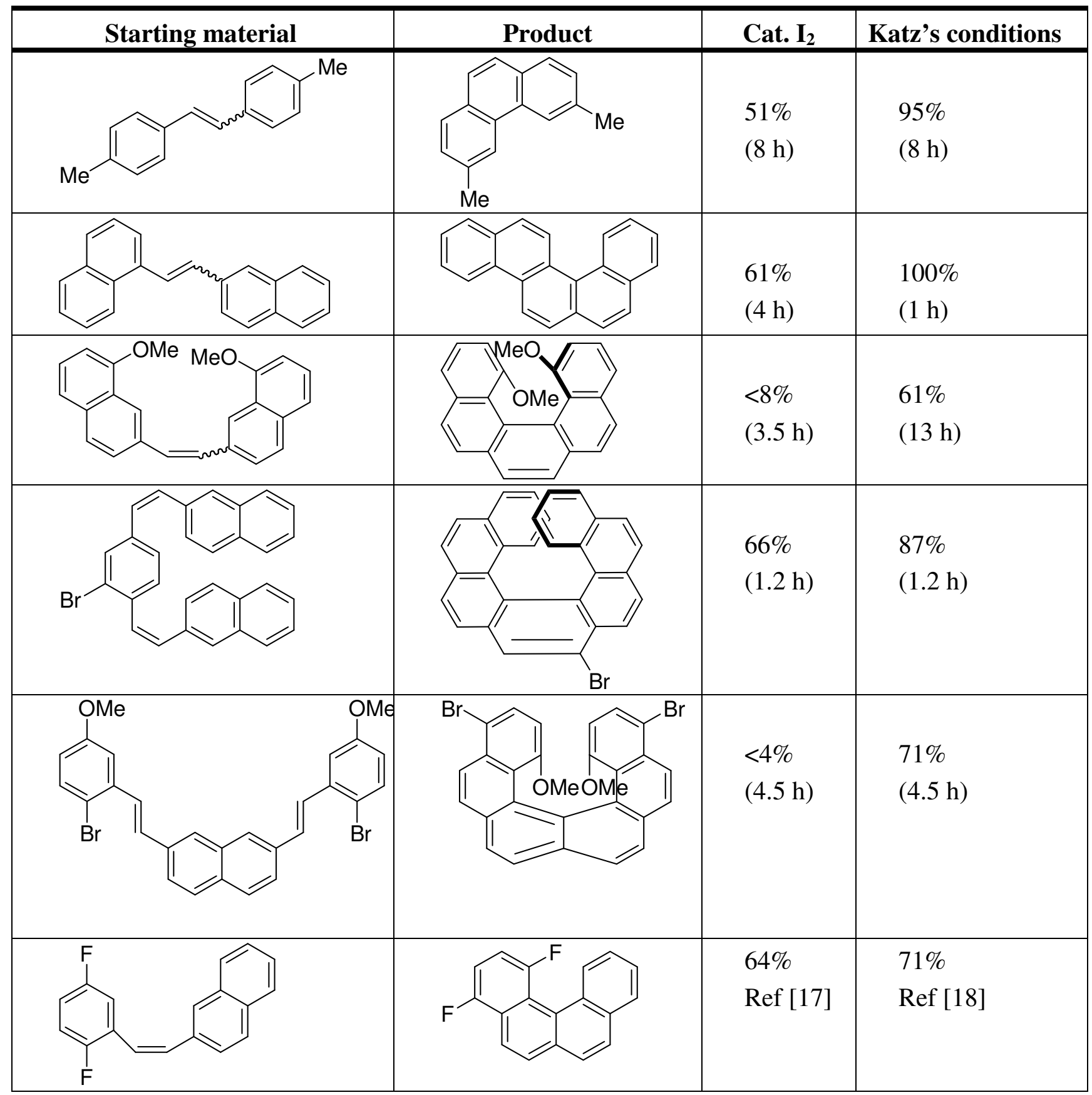

Less reactive molecules that remain unreactive in other photochemical conditions sometimes react under Katz-conditions [19], as shown in Scheme 3, below. 
Scheme 3. Photochemical cyclization of a less reactive molecule.
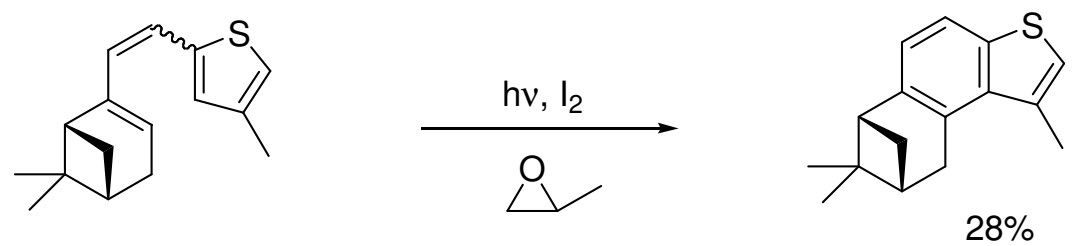

The conditions are compatible with a wide range of functionality, as illustrated in Scheme 4 . The high concentration of iodine allows for a higher concentration of starting materials in the reaction without formation of dimers as a side-reaction. This is illustrated in some patents [20-22] describing a photocyclization with $5 \mathrm{~g}$ starting material per liter of solvent. Also in our experience this is about the concentration limit to avoid significant side reactions under Katz-conditions [23]. Reaction times depend on concentrations, but Katz's conditions are often faster than using catalytic amounts of iodine [24]. Recently, potassium carbonate has also been introduced as a HI-scavenger to prevent ring opening of the alkyl chains [25] (Scheme 5). Further examples of reactions with Katz-conditions are given in Appendix II.

Scheme 4. Example of highly functionalized molecule that is compatible with the Mallory condition under Katz's conditions [26].

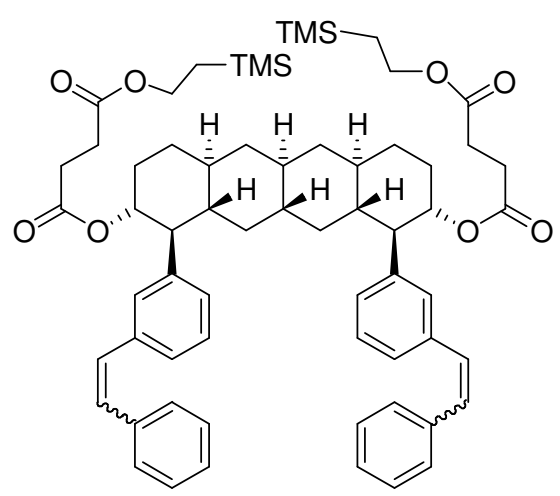
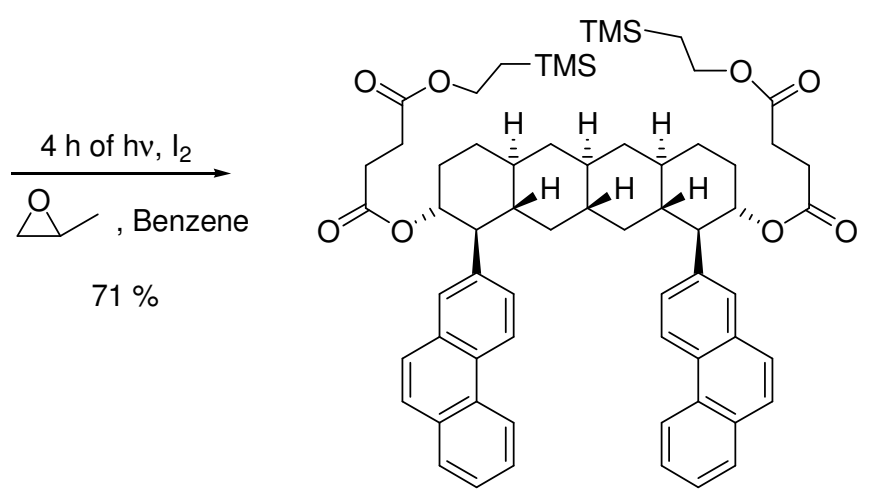

Scheme 5. Potassium carbonate as HI-scavenger [25].

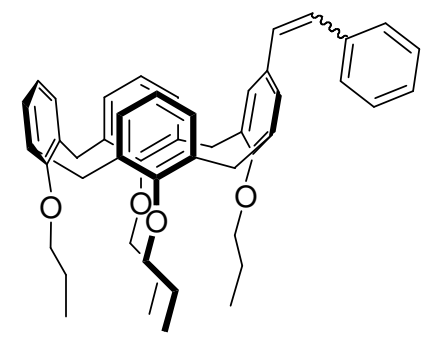

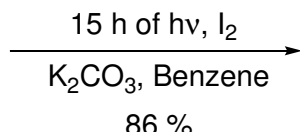

$86 \%$

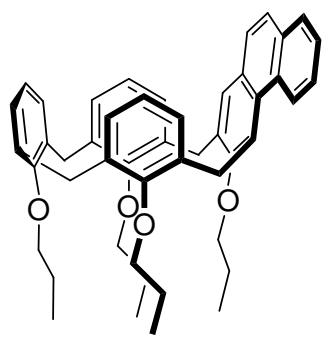

\section{Elimination Photocyclizations}

The original $\mathrm{I}_{2} / \mathrm{O}_{2}$-conditions sometimes give significant amounts of byproducts from elimination of $o$-methoxy-groups on the stilbenes [27]. Finnie [28] avoided the problem of elimination of methanol by putting methoxy-groups at both ortho-positions (Scheme 6). 
Scheme 6. Elimination of either orto-methoxy-group gave the same product.<smiles>COc1cc(OC)cc(/C(C)=C(\OC(C)=O)c2c(OC)cc(C)cc2OC)c1</smiles>

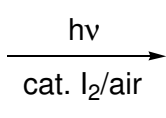<smiles>COc1cc(OC)c2c(c1)c(OC(C)=O)c(C#N)c1c(OC)cc(C)cc12</smiles>

However, with less symmetrical starting materials this is not a viable approach. Katz-conditions will usually reduce the problem of this kind of elimination.

Mallory [29] tested acidic conditions to promote elimination of methanol to control the selectivity. The reactions needed much longer reaction times. Some selectivity towards elimination was achieved with catalytic amounts of sulfuric acid, at the cost of lower yields than with oxidative conditions on the same stilbenes. The reactions were not inverted in all cases, but a good selective synthesis of 2-methylphenanthrene and 4-methylphenanthrene was obtained (Scheme 7). Oxidative cyclization of metamethylstilbene gives a 1:1 mixture of these regioisomers that are difficult to separate. However, attempts to control the cyclization into the unfavored benzo[a]anthracene failed.

It is also possible to put a good leaving group like tosyl at the bridge-double bond to promote cyclization under basic conditions [30]. Although this gave very good yields, it does not help to control the selectivity of the cyclization.

Scheme 7. Eliminative photocyclization used to avoid the selectivity-problem with substituents in meta-position on the stilbene [29].<smiles>COc1ccc(C)cc1C=Cc1ccccc1</smiles><smiles>[H][R5](O)(O)OCC</smiles>

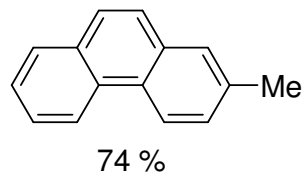

Table 2. Comparison of product formation between oxidative and basic elimination conditions [31].

\begin{tabular}{|c|c|c|c|c|c|c|}
\hline $\mathbf{X}$ & $\mathbf{R}_{1}$ & $\mathbf{R}_{2}$ & Conditions & $\mathbf{a}$ & $\mathbf{b}$ & Product ratio \\
\hline \multirow[t]{2}{*}{$\mathrm{Cl}$} & $\mathrm{CH}_{3}$ & $\mathrm{H}$ & Oxidative & 95 & 0 & $>20$ \\
\hline & & & Basic & 8 & 31 & 4.0 \\
\hline \multirow[t]{2}{*}{$\mathrm{Br}$} & $\mathrm{CH}_{3}$ & $\mathrm{H}$ & Oxidative & 65 & 0 & $>20$ \\
\hline & & & Basic & 16 & 20 & 1.3 \\
\hline \multirow{2}{*}{$\mathrm{Br}$} & $\mathrm{OCH}_{3}$ & $\mathrm{H}$ & Oxidative & 71 & 7 & 10 \\
\hline & & & Basic & 10 & 41 & 4.1 \\
\hline \multirow[t]{2}{*}{$\mathrm{Br}$} & $\mathrm{OCH}_{2} \mathrm{O}$ & & Oxidative & 63 & 12 & 5.3 \\
\hline & & & Basic & 0 & 57 & $>20$ \\
\hline
\end{tabular}

Dehydrobromination under basic conditions has been extensively studied, but it also has its limitations. Olsen [31] did a comparison between oxidative photocyclizations (2 equivalents of iodine) and elimination photocyclizations with $\mathrm{NaOMe}$ in methanol. Some of the results are summarized in 
Table 2. The yields of oxidative conditions were consistently higher, but some debrominations were observed as secondary reactions occurring after the cyclization. The basic conditions did change the selectivity, but to a lesser degree than desired. As can be seen in the last example, basic conditions can give very good selectivity, but only when the system is already inclined to react that way. Some more examples of eliminative photocyclizations are summarized in Appendix 3. However, this approach has generally been of limited use.

\section{Reactivity Parameters}

The Mallory-reaction is somewhat sensitive to steric effects of the substituents, as shown in Scheme 8 , although the product distribution does not deviate much from a statistical distribution.

Scheme 8. Oxidative photocyclization with two meta-substituents. The product composition deviates only a bit from a statistical distribution and towards less steric hindrance [32].

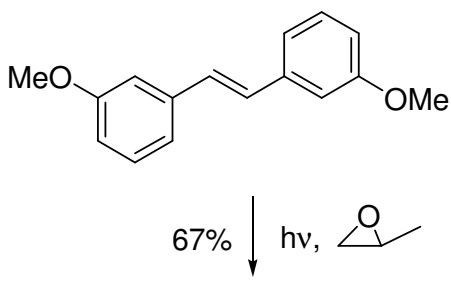



a

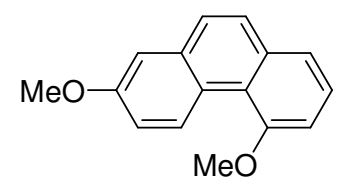

$\underline{\mathbf{b}}$

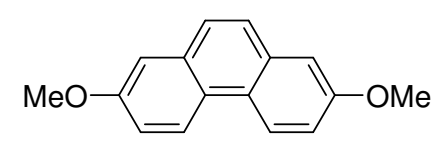

$\underline{\mathbf{c}}$

Obtained: $\quad \underline{\mathbf{a}}: \underline{\mathbf{b}}: \underline{\mathbf{c}}=16: 55: 29$

Statistical ratio: $\underline{\mathbf{a}}: \underline{\mathbf{b}}: \underline{\mathbf{c}}=\mathbf{2 5 : 5 0 : 2 5}$

In contrast, the aromatic ring-structure regioselectivity of the Mallory-reaction is very strong. Usually only one ring-structure is formed, even when the formation of several structures look plausible. The reaction favors ring-structures that are curled towards helicene structures as the two examples in Scheme 9 show.

Laarhoven [6,10] has evaluated reactivity parameters like free valence numbers [35] $\left(\sum \mathrm{F}_{r s}^{*}\right)$ and localization energies $\left(\sum \mathrm{L}_{r s}^{*}\right)$ for a large number of examples. He found a good correlation between these two parameters, but found free valence numbers more convenient as only one calculation is needed to evaluate all cyclization modes of a particular compound. $\sum \mathrm{F}_{r s}{ }_{r s}$ is the sum of the free valence numbers of atoms $r$ and $s$ involved in the cyclization in the exited state $\left(\mathrm{F}_{r}=\sqrt{3}-\sum \mathrm{P}\right.$ in which $\mathrm{P}$ is the bond order).

Three rules [6] for cyclization were determined:

(i) Photocyclizations do not occur when $\sum \mathrm{F}_{r s}{ }_{r}<1.0$.

(ii) When two or more cyclizations are possible in a particular compound, only one product arises if $\Delta\left(\sum \mathrm{F}_{r s}{ }^{*}\right)>0.1$; more products are formed if the differences are smaller. 
(iii) The second rule holds when only planar or non-planar products (penta- or higher helicenes) can arise. When planar as well as non-planar products can be formed, the planar aromatic in general is the main product, provided that for its formation $\sum \mathrm{F}_{r s}{ }_{r s}>1.0$

Scheme 9. Oxidative photocyclization often gives one main regioisomer. A) Ref. [33], B) Ref. [34].

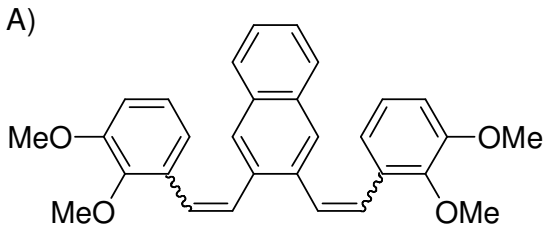

B)<smiles>C(=C/c1ccc2ccccc2c1)\c1cccc(/C=C/c2ccc3ccccc3c2)c1</smiles>
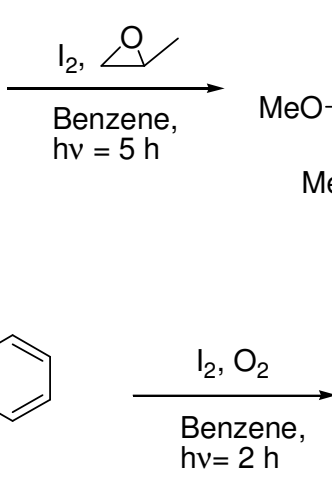



$91 \%$



Photocyclization of 1,4-distyrylbenzene [6] is a good example (Scheme 10). Another example applies to 1,3-distyrylbenzene [8]. The best discussion with several reaction examples with calculated reactivity parameters is given in a review by Laarhoven [10]. These rules should be a useful planning tool for synthesis, but no examples have been found where these rules have actually been applied in the such planning. One reason might be that the theory and calculations of these reaction parameters are not very accessible for the typical synthesis chemist with a limited background in theoretical chemistry.

Scheme 10. Calculation of $\sum \mathrm{F}^{*}{ }_{r s}$ for the reaction indicates that methyl-substituted distyrylbenzene can undergo photocyclization, but not the unsubstituted compound. Experiments are in accordance with this $[6,36]$.

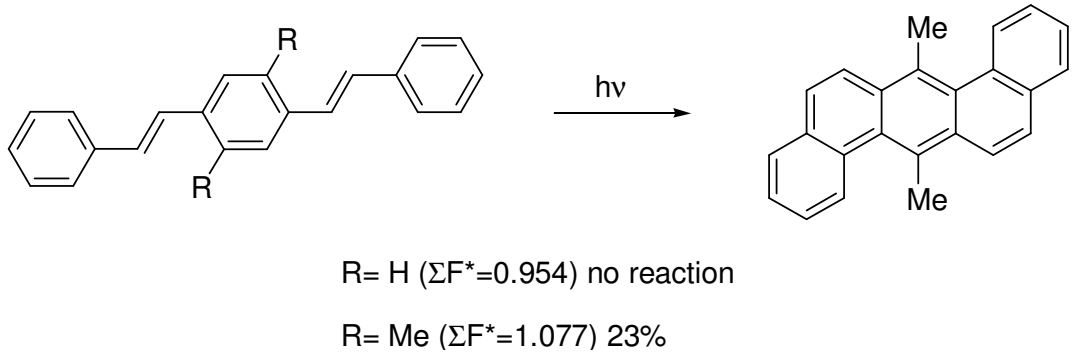

\section{Controlling Product Formation with Blocking Groups}

Helicenes are borderline molecules in Laarhoven's cyclization rules. When they become larger than five benzene rings they become non-planar, and thus no longer favored products. Formation of planar $\mathrm{S}$-shaped molecules becomes the main side reaction or even the main reaction. This led Katz's group to develop the bromo-group as a directing substituent $[15,16,37]$. The bromo-group also blocks its neighbor position in the cyclization (Scheme 11): 
Scheme 11. Br is used as a blocking group.


Without the bromo-group the reaction gives 1:1 [7]helicene and the S-shaped benzo[a]naphto[1,2k]tetraphene [15]. Without blocking groups the yield of [6]helicenes also becomes low [38]. The bromo-group can even protect neighbouring methoxy-groups from elimination-cyclization. Without the bromo-groups in the example below a mixture of the desired product and products resulting from elimination reactions occurred [37] (Scheme 12):

Scheme 12. Br also protects neighbouring methoxy-groups from elimination-cyclization.<smiles>COc1cc(Br)c(OC)c(/C=C/c2ccc(OC)c(OC)c2)c1</smiles>
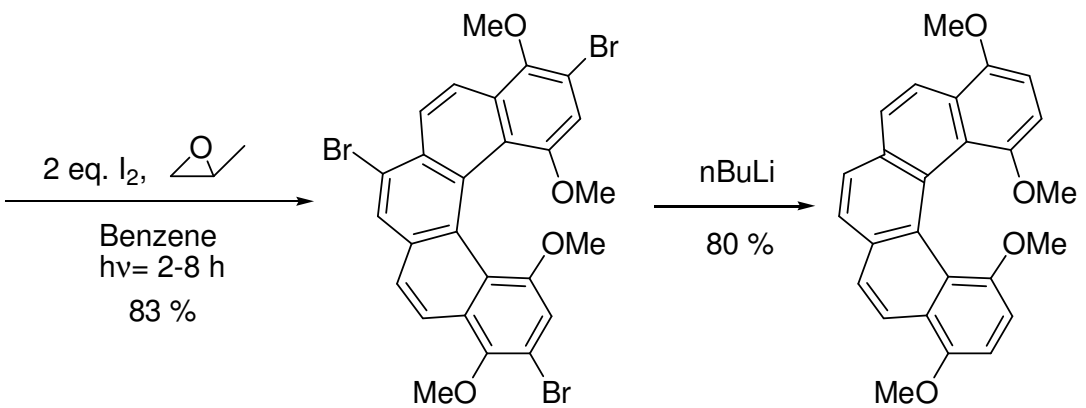

It has proven more difficult to use blockers to change the regioselectivity into anthracene-like moieties. Amin [39] experienced low yields and further oxidation of the bromo-group into quinones while trying to force the reaction away from benzo[c]phenanthrene and towards benzo[a]anthracene. Harvey tested different blocking groups and concluded that the chloro-group works better [40]. There is still a price to pay for working against the natural pathway as illustrated in Scheme 13. In PAHsynthesis the Mallory-reaction encounters competition from other methods for several ringsystems $[41,42]$.

The overlapping helicenes are chiral, and have very large specific rotation $\left([\alpha]_{25}^{\mathrm{D}}=3640^{\circ}\right.$ for [6]helicene [44]). This allowed for a study of the small enantioselectivities induced by chiral solvents during the Mallory-reaction [44].

Inflexible chiral groups on the substrate for a double Mallory-reaction gave a [7]helicene with better enantiomeric excess than the starting material (Scheme 14) [16]. The use of more flexible chiral auxiliaries like menthol on a carboxylic acid substituent gave lower diastereoselectivities in the formation of [5]- and [6]helicenes [45]. 
Scheme 13. Examples from ref. [43]. In A) the reaction follows the natural cyclization path but the chloro-group prevents the 50:50 product mixture from meta-methyl. In B) the chloro-groups blocks the preferred cyclization path and forces the product formation.

A)<smiles>COc1cccc(C=Cc2cccc(C)c2Cl)c1OC</smiles>

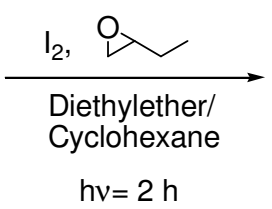<smiles>COc1ccc2c(ccc3c(Cl)c(C)ccc32)c1OC</smiles>

B)<smiles>COc1ccc2c(ccc3c(Cl)c(/C=C\c4cccc(OC)c4OC)ccc32)c1</smiles>

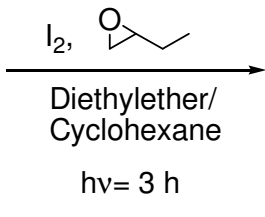<smiles>COc1ccc2c(ccc3c(Cl)c4ccc5c(OC)c(OC)ccc5c4cc32)c1</smiles>

Scheme 14. Synthesis of a chiral helicene-system obtained with a double Mallory-reaction with $\mathrm{Br}$ as a blocking group. The two chiral groups get placed on the outside of the helicene to avoid unnecessary bending of the aromatic system [16].

2<smiles>CCO[C@H]1CCc2c1ccc1ccc(C=O)cc21</smiles>

$48 \%$ ee<smiles>O=P(O)(Cc1ccc(C[PbH](Br)Br)cc1Br)c1ccccc1</smiles>

1. $t$-BuLi 2. $\mathrm{TsOH}, \Delta$

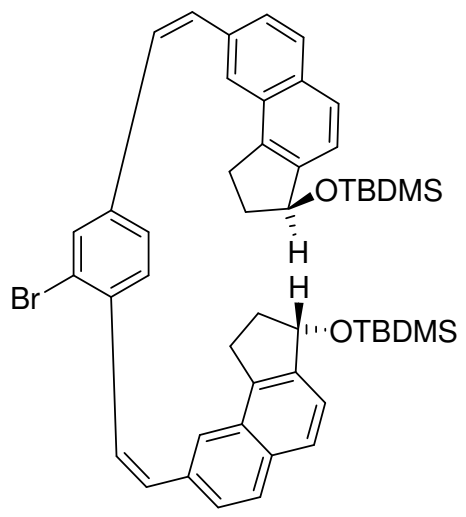

2.2 eq. $I_{2}$ Methyloxirane Benzene, $h v=12 \mathrm{~h}$

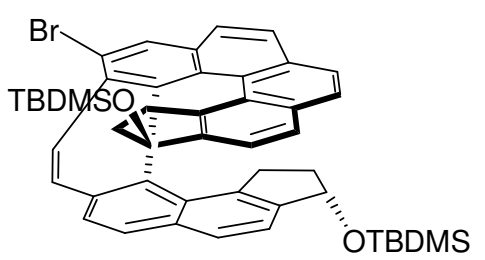

The reaction has lately also made its way into material science [46,47]. It is appropriate to end this review with a series of papers by Mallory [48-50], the latest 37 years after the publication of the use of iodine as a catalyst [3]. Here [48] steric hindrance allows formation of carbon-ribbons (phenacenes) (Scheme 15): 
Scheme 15. Photochemical synthesis of phenacenes.
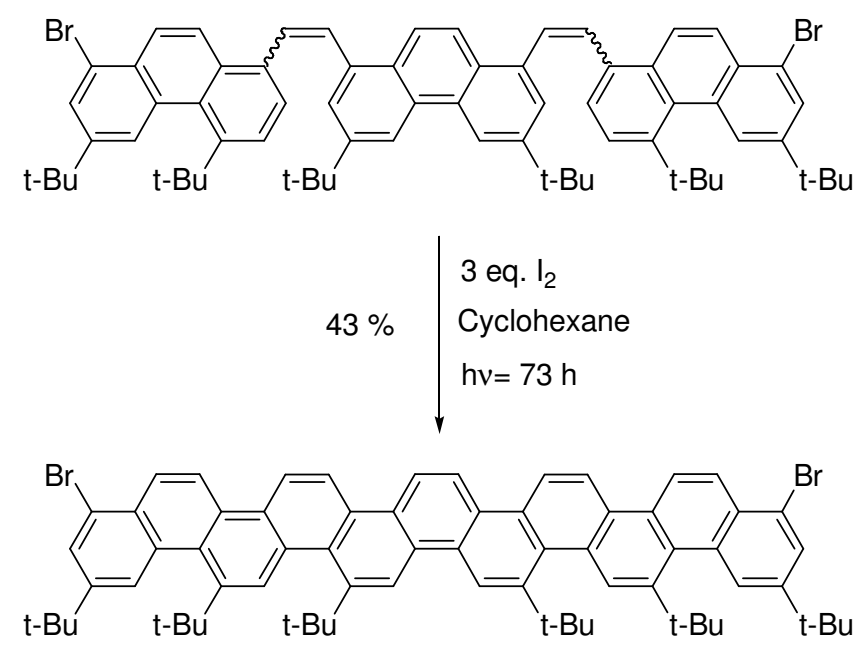

\section{References}

1. Smakula, A. The photochemical transformation of trans-stilbene. 1934, B25, 90-98.

2. Buckles, R.E. Illumination of cis- and trans-stilbenes in dilute solutions. J. Am. Chem. Soc. 1955, 77, 1040-1041.

3. Mallory, F.B.; Wood, C.S.; Gordon, J.T. Photochemistry of Stilbenes. III. Some Aspects of the Mechanism of Photocyclization to Phenanthrenes. J. Am. Chem. Soc. 1964, 86, 3094-3102.

4. Mallory, F.B.; Wood, C.S. Photochemistry of Stilbenes IV. The Preparation of Substituted Phenyanthrenes. J. Org. Chem. 1964, 29, 3374-3377.

5. Mallory, F.B.; Mallory, C.W. Photocyclization of stilbenes and related molecules. Org. React. 1984, 30 .

6. Laarhoven, W.H. Photochemical cyclizations and intramolecular cycloadditions of conjugated arylolefins. Part I: Photocyclization with dehydrogenation. Rec. Trav. Chim.-J. Roy. Neth. Chem. 1983, 102, 185-204.

7. Hagen, S.; Hopf, H. Modern routes to extended aromatic compounds. In Carbon Rich Compounds I; Springer-Verlag Berlin: Berlin, Germany, 1998; Volume 196, pp. 45-89.

8. Meier, H. The photochemistry of stilbenoid compounds and their role in materials technology. Angew. Chem. Int. Ed. Eng. 1992, 31, 1399-1420.

9. Tominaga, Y.; Castle, R.N. Photocyclization of aryl- and heteroaryl-2-propenoic acid derivatives. Synthesis of polycyclic heterocycles. J. Heterocycl. Chem. 1996, 33, 523-538.

10. Laarhoven, W.H. Photocyclizations and intramolecular photocycloadditions of conjugated arylolefins and related compounds. Org. Photochem. 1989, 10, 163-308.

11. Mori, T.; Inoue, Y. C $=\mathrm{C}$ photoinduced isomerization reactions. Mol. Supramol. Photochem. 2005, $12,417-452$.

12. Zertani, R.; Meier, H. Photochemistry of 1,3-distyrylbenzene. A new route to syn[2.2](1,3)cyclophanes. Chem. Ber. 1986, 119, 1704-1715.

13. Noller, K.; Kosteyn, F.; Meier, H. Photochemistry of electron-rich 1,3-distyrylbenzenes. Chem. Ber. 1988, 121, 1609-1616. 
14. Liu, L.; Yang, B.; Katz, T.J.; Poindexter, M.K. Improved methodology for photocyclization reactions. J. Org. Chem. 1991, 56, 3769-3775.

15. Sudhakar, A.; Katz, T.J. Directive effect of bromine on stilbene photocyclizations. An improved synthesis of [7]helicene. Tetrahedron Lett. 1986, 27, 2231-2234.

16. Sudhakar, A.; Katz, T.J.; Yang, B. Synthesis of a helical Metallocene Oligomer. J. Am. Chem. Soc. 1986, 108, 2790-2791.

17. Bae, S.; Mah, H.; Chaturvedi, S.; Jeknic, T.M.; Baird, W.M.; Katz, A.K.; Carrell, H.L.; Glusker, J.P.; Okazaki, T.; Laali, K.K.; Zajc, B.; Lakshman, M.K. Synthetic, crystallographic, computational, and biological studies of 1,4-difluorobenzo c phenanthrene and its metabolites. $J$. Org. Chem. 2007, 72, 7625-7633.

18. Plater, M.J. Synthesis of benzo[ghi]fluoranthenes from 1-halobenzo[c]phenanthrenes by flash vacuum pyrolysis. Tetrahedron Lett. 1994, 35, 6147-6150.

19. Wigglesworth, T.J.; Sud, D.; Norsten, T.B.; Lekhi, V.S.; Branda, N.R. Chiral discrimination in photochromic helicenes. J. Am. Chem. Soc. 2005, 127, 7272-7273.

20. Chau, A.; Cote, B.; Ducharme, Y.; Frenette, R.; Friesen, R.; Gagnon, M.; Giroux, A.; Martins, E.; $\mathrm{Yu}, \mathrm{H}$; $\mathrm{Wu}, \mathrm{T}$. Preparation of 2-(phenyl or heterocyclyl)-1H-phenanthro[9,10-d]imidazoles as microsomal prostaglandin E synthase-1 (mPGES-1) enzyme inhibitors. WO 2007/059610, 31 May 2007.

21. Chau, A.; Cote, B.; Ducharme, Y.; Frenette, R.; Friesen, R.; Gagnon, M.; Giroux, A.; Martins, E.; $\mathrm{Yu}, \mathrm{H}$.; Hamel, P. Preparation of phenanthro[9,10-d]imidazoles as inhibitors of microsomal prostaglandin E synthase-1 (mPGES-1). WO 2007/095753, 30 August 2007.

22. Chau, A.; Cote, B.; Ducharme, Y.; Frenette, R.; Friesen, R.; Gagnon, M.; Giroux, A.; Martins, E.; $\mathrm{Yu}, \mathrm{H}$.; Wu, T. Preparation of 1H-phenanthro[9,10-d]imidazoles as mPGES-1 inhibitors. WO 2006/063466, 22 June 2006.

23. Jorgensen, K.B.; Joensen, M. Photochemical synthesis of chrysenols. Polycycl. Aromat. Compound. 2008, 28, 362-372.

24. Kretzschmann, H.; Muller, K.; Kolshorn, H.; Schollmeyer, D.; Meier, H. Triphenanthro-anellated 18 annulenes with alkoxy side-chains - A novel class of discotic liquid-crystals. Chem. Ber. 1994, $127,1735-1745$.

25. Mastalerz, M.; Hueggenberg, W.; Dyker, G. Photochemistry of styrylcalix[4]arenes. Eur. J. Org. Chem. 2006, 3977-3987.

26. Nemoto, H.; Kawano, T.; Ueji, N.; Sakamoto, N.; Araki, T.; Miyoshi, N.; Suzuki, I.; Shibuya, M. Synthesis of a water-soluble molecular tweezer and a recognition study in an aqueous media. Tetrahedron Lett. 2005, 46, 551-553.

27. Duclos, R.I., Jr.; Tung, J.S.; Rapoport, H. A high-yield modification of the Pschorr phenanthrene synthesis. J. Org. Chem. 1984, 49, 5243-5246.

28. Finnie, A.A.; Hill, R.A. The synthesis of 1,5,7,10-tetraoxygenated 3-methylphenanthrenes. $J$. Chem. Res., Synop. 1987, 78-79.

29. Mallory, F.B.; Rudolph, M.J.; Oh, S.M. Photochemistry of stilbenes. 8. Eliminative photocyclization of o-methoxystilbenes. J. Org. Chem. 1989, 54, 4619-4626. 
30. Almeida, J.F.; Castedo, L.; Fernandez, D.; Neo, A.G.; Romero, V.; Tojo, G. Base-Induced Photocyclization of 1,2-Diaryl-1-tosylethenes. A Mechanistically Novel Approach to Phenanthrenes and Phenanthrenoids. Org. Lett. 2003, 5, 4939-4941.

31. Olsen, R.J.; Pruett, S.R. Photocyclization of o-halostilbenes. J. Org. Chem. 1985, 50, 5457-5460.

32. Dyker, G.; Koerning, J.; Stirner, W. Synthesis and photocyclization of macrocyclic stilbene derivatives. Eur. J. Org. Chem. 1998, 149-154.

33. Zhang, F.J.; Harvey, R.G. Syntheses of fjord region bis-dihydrodiol and bis-anti-diol epoxide metabolites of benzo s picene. J. Org. Chem. 1998, 63, 1168-1171.

34. Mallory, F.B.; Mallory, C.W.; Sen Loeb, S.E. Photochemistry of stilbenes. 7. Formation of a dinaphthanthracene by a stilbene-like photocyclization. Tetrahedron Lett. 1985, 26, 3773-3776.

35. Scholz, M.; Mühlstädt, M.; Dietz, F. Chemie Angeregter Zustände. I. Mitt die Richlung der Photocycliserung Naphthalinsubstituerter Äthylene. Tetrahedron Lett. 1967, 665-668.

36. Blum, J.; Zimmerman, M. Photocyclization of substituted 1,4-distyrylbenzenes to dibenz[a,h]anthracenes. Tetrahedron 1972, 28, 275-280.

37. Liu, L.; Katz, T.J. Bromine auxiliaries in photosynthesis of [5]helicenes. Tetrahedron Lett. 1991, 32, 6831-6834.

38. Aloui, F.; El Abed, R.; Guerfel, T.; Ben Hassine, B. Synthesis and X-Ray Analysis of a New [6]Helicene. Synth. Commun. 2006, 36, 1557-1567.

39. Desai, D.; Krzeminski, J.; Amin, S. Convenient synthesis of 3-methoxybenz[a]anthracene-7,12dione. Chem. Res. Toxicol. 1994, 7, 722-723.

40. Harvey, R.G.; Dai, W.; Zhang, J.T.; Cortez, C. Synthesis of potentially carcinogenic higher oxidized metabolites of dibenz a,j anthracene and benzo c chrysene. J. Org. Chem. 1998, 63, 8118-8124.

41. Harvey, R.G.; Zhang, F.J. New synthetic approaches to PAHs and their carcinogenic metabolites. Polycycl. Aromat. Compound. 2002, 22, 231-237.

42. Zhang, F.J.; Cortez, C.; Harvey, R.G. New synthetic approaches to polycyclic aromatic hydrocarbons and their carcinogenic oxidized metabolites: Derivatives of benzo s picene, benzo rst pentaphene, and dibenzo b, def chrysene. J. Org. Chem. 2000, 65, 3952-3960.

43. Zhang, J.-T.; Dai, W.; Harvey, R.G. Synthesis of Higher Oxidized Metabolites of Dibenz[a,j]anthracene Implicated in the Mechanism of Carcinogenesis. J. Org. Chem. 1998, 63, 8125-8132.

44. Prinsen, W.J.C.; Laarhoven, W.H. The influence of the chiral environment in the photosynthesis of enantiomerically enriched hexahelicene. Rec. Trav. Chim.-J. Roy. Neth. Chem. 1995, 114, 470.

45. Pearson, M.S.M.; Carbery, D.R. Studies toward the Photochemical Synthesis of Functionalized [5]- and [6]Carbohelicenes. J. Org. Chem. 2009, 74, 5320-5325.

46. Xiao, S.; Tang, J.; Beetz, T.; Guo, X.; Tremblay, N.; Siegrist, T.; Zhu, Y.; Steigerwald, M.; Nuckolls, C. Transferring Self-Assembled, Nanoscale Cables into Electrical Devices. J. Am. Chem. Soc. 2006, 128, 10700-10701.

47. Misra, B.; Amin, S. An improved synthesis of anti-benzo[c]phenanthrene-3,4-diol-1,2-epoxide via 4-methoxybenzo[c]phenanthrene. J. Org. Chem. 1990, 55, 4478-4480. 
48. Mallory, F.B.; Butler, K.E.; Berube, A.; Luzik, E.D.; Mallory, C.W.; Brondyke, E.J.; Hiremath, R.; Ngo, P.; Carroll, P.J. Phenacenes: a family of graphite ribbons. Part 3: Iterative strategies for the synthesis of large phenacenes. Tetrahedron 2001, 57, 3715-3724.

49. Mallory, F.B.; Butler, K.E.; Evans, A.C.; Brondyke, E.J.; Mallory, C.W.; Yang, C.; Ellenstein, A. Phenacenes: A Family of Graphite Ribbons. 2. Syntheses of Some [7]Phenacenes and an [11]Phenacene by Stilbene-like Photocyclizations. J. Am. Chem. Soc. 1997, 119, 2119-2124.

50. Mallory, F.B.; Butler, K.E.; Evans, A.C.; Mallory, C.W. Phenacenes: a family of graphite ribbons. 1. Synthesis of some [7]phenacenes by stilbene-like photocyclizations. Tetrahedron Lett. 1996, 37, 7173-7176.

51. Puls, C.; Stolle, A.; de Meijere, A. Preparation and properties of new methano-bridged dibenzo[c,g]phenanthrenes. Chem. Ber. 1993, 126, 1635-1641.

52. Ho, T.I.; Shu, C.S.; Yeh, M.K.; Chen, F.C. A novel synthetic approach to biphenyls. Synthesis 1987, 795-797.

53. Bhandari, S.R.; Kapadi, A.H. Synthesis of eulophiol dimethyl ether. Indian J. Chem. Sect. B 1985, 24B, 204-205.

54. Meier, H.; Kretzschmann, H.; Kolshorn, H. [abc]-Annelated [18]annulenes. J. Org. Chem. 1992, 57, 6847-6852.

55. Langenegger, S.M.; Haner, R. The effect of a non-nucleosidic phenanthrene building block on DNA duplex stability. Helv. Chim. Acta 2002, 85, 3414-3421.

56. Khalaf, A.I.; Pitt, A.R.; Scobie, M.; Suckling, C.J.; Urwin, J.; Waigh, R.D.; Fishleigh, R.V.; Young, S.C.; Wylie, W.A. The synthesis of some head to head linked DNA minor groove binders. Tetrahedron 2000, 56, 5225-5239.

57. Carme Pampin, M.; Estevez, J.C.; Estevez, R.J.; Maestro, M.; Castedo, L. Heck-mediated synthesis and photochemically induced cyclization of [2-(2-styrylphenyl)ethyl]carbamic acid ethyl esters and 2-styrylbenzoic acid methyl esters: Total synthesis of naphtho[2,1f]isoquinolines (2-azachrysenes). Tetrahedron 2003, 59, 7231-7243.

58. Pampin, C.; Estevez, J.C.; Castedo, L.; Estevez, R.J. Palladium-mediated total synthesis of 2styrylbenzoic acids: a general route to 2-azachrysenes. Tetrahedron Lett. 2002, 43, 4551-4553.

59. Kaliakoudas, D.; Eugster, C.H.; Ruedi, P. Synthesis of plectranthones, diterpenoid phenanthrene1,4-diones. Helv. Chim. Acta 1990, 73, 48-62.

60. Estevez, J.C.; Villaverde, M.C.; Estevez, R.J.; Seijas, J.A.; Castedo, L. New total synthesis of phenanthrene alkaloids. Can. J. Chem. 1990, 68, 964-968.

61. Pampin, M.C.; Estevez, J.C.; Estevez, R.J.; Suau, R.; Castedo, L. First total syntheses of the 1,2,3,4-tetrahydronaphtho[2,1-f]isoquinolines annoretine and litebamine. Tetrahedron 2003, 59, 8057-8065.

62. Martinez, E.; Estevez, J.C.; Estevez, R.J.; Castedo, L. Photochemically induced cyclization of N[2-(o-styryl)phenylethyl]acetamides and 5-styryl-1-methyl-1,2,3,4-tetrahydroisoquinolines: New total syntheses of 1-methyl-1,2,3,4-tetrahydronaphtho[2,1-f]isoquinolines. Tetrahedron 2001, 57, 1981-1986.

63. Schneider, M.R.; Schiller, C.D. Hydroxy substituted 10-ethyl-9-phenylphenanthrenes. Compounds for the investigation of the influence of E,Z-isomerization on the biological 
properties of mammary tumor-inhibiting 1,1,2-triphenylbutenes. Arch. Pharm. 1987, 320, 159-166.

64. Moody, C.J.; Rees, C.W.; Young, R.G. Synthesis and properties of 4H-imidazoles. Part 2. J. Chem. Soc. Perkin Trans. 1 1991, 335-339.

65. Hopf, H.; Hucker, J.; Ernst, L. Paracyclophanes. Part 58. On the use of the stilbene-phenanthrene photocyclization in 2.2 paracyclophane chemistry. Polish J. Chem. 2007, 81, 947-969.

66. Koizumi, Y.; Suzuki, S.; Takeda, K.; Murahashi, K.; Horikawa, M.; Katagiri, K.; Masu, H.; Kato, T.; Azumaya, I.; Fujii, S.; Furuta, T.; Tanaka, K.; Kan, T. Synthesis and characteristic stereostructure of a biphenanthryl ether. Tetrahedron Asymmetry 2008, 19, 1407-1410.

67. Takeuchi, M.; Nishimura, J. Intramolecular [2+2]-photocycloaddition. 19. 1,2-Ethano-syn[2.n](1,6)phenanthrenophanes; first isolated syn-phenanthrenophanes. Tetrahedron Lett. 1992, 33, 5563-5566.

68. Zimmermann, T.J.; Muller, T.J.J. The first synthesis and electronic properties of tetrakis[(hetero)phenanthrenyl]methanes. Eur. J. Org. Chem. 2002, 2269-2279.

69. Yamashita, S.; Kurono, N.; Senboku, H.; Tokuda, M.; Orito, K. Synthesis of phenanthro[9,10b]indolizidin-9-ones, phenanthro[9,10-b]quinolizidin-9-one, and related benzolactams by $\mathrm{Pd}(\mathrm{OAc}) 2-$ catalyzed direct aromatic carbonylation. Eur. J. Org. Chem. 2009, 1173-1180.

70. Purushothaman, E.; Pillai, V.N.R. Photoreactions of 4,5-diarylimidazoles: Singlet oxygenation and cyclodehydrogenation. Indian J. Chem. Sect. B 1989, 28B, 290-293.

71. Kuo, C.-H.; Tsau, M.-H.; Weng, D.T.C.; Lee, G.H.; Peng, S.-M.; Luh, T.-Y.; Biedermann, P.U.; Agranat, I. Oxidative Photocyclization of Tethered Bifluorenylidenes and Related Compounds. $J$. Org. Chem. 1995, 60, 7380-7381.

72. Sabitha, G.; Reddy, G.J.; Rao, A.V.S. Synthesis of 3-phenylbenzo[g][1]benzopyrano[4,3e]indazol-8(3H)-ones and benzo[b]phenanthro[9,10-d]pyran-9-ones by photooxidation of 3-aryl4-(1-phenyl-1H-pyrazol-4-yl)coumarins and 3,4-diarylcoumarins. Synth. Commun. 1988, 18, 639-649.

73. Moorthy, J.N.; Venkatakrishnan, P.; Sengupta, S.; Baidya, M. Facile synthesis, fluorescence, and photochromism of novel helical pyrones and chromenes. Org. Lett. 2006, 8, 4891-4894.

74. Tominaga, Y.; Castle, R.N.; Lee, M.L. Synthesis of aminochrysenes by the oxidative photocyclization of acetylaminostilbenes. Chem. Pharm. Bull. 1993, 41, 1853-1855.

75. Mallory, F.B.; Mallory, C.W.; Ricker, W.M. Nuclear spin-spin coupling via nonbonded interactions. 4. Fluorine-fluorine and hydrogen-fluorine coupling in substituted benzo[c]phenanthrenes. J. Org. Chem. 1985, 50, 457-461.

76. Utermoehlen, C.M.; Singh, M.; Lehr, R.E. Fjord region 3,4-diol 1,2-epoxides and other derivatives in the 1,2,3,4- and 5,6,7,8-benzo rings of the carcinogen benzo[g]chrysene. J. Org. Chem. 1987, 52, 5574-5582.

77. Seidel, A.; Glatt, H.R.; Oesch, F.; Garrigues, P. 2,9-Dimethylpicene: synthesis, mutagenic activity, and identification in natural samples. Polycycl. Aromat. Compound. 1990, 1, 3-14.

78. Fields, E.K.; Behrend, S.J.; Meyerson, S.; Winzenburg, M.L.; Ortega, B.R.; Hall, H.K. Diarylsubstituted maleic anhydrides. J. Org. Chem. 1990, 55, 5165-5170. 
79. Lawrence, N.J.; Ghani, F.A.; Hepworth, L.A.; Hadfield, J.A.; McGown, A.T.; Pritchard, R.G. The synthesis of (E)- and (Z)-combretastatins A-4 and a phenanthrene from Combretum caffrum. Synthesis 1999, 1656-1660.

80. Schnorpfeil, C.; Fetten, M.; Meier, H. Synthesis of tripyreno[2,3,4-abc:2,3,4-ghi:2,3,4mno][18]annulenes. J. Prakt. Chem. 2000, 342, 785-790.

81. Nakamura, Y.; Yamazaki, T.; Nishimura, J. Synthesis and Fluorescence Spectra of Oxa[3.n]phenanthrenophanes. Org. Lett. 2005, 7, 3259-3262.

82. Nakamura, Y.; Fujii, T.; Nishimura, J. Synthesis and fluorescence emission behavior of anti[2.3](3,10)phenanthrenophane: Overlap between phenanthrene rings required for excimer formation. Chem. Lett. 2001, 970-971.

83. Kelly, T.R.; Sestelo, J.P.; Tellitu, I. New molecular devices: In search of a molecular ratchet. $J$. Org. Chem. 1998, 63, 3655-3665.

84. Plater, M.J. Fullerene tectonics .2. Synthesis and pyrolysis of halogenated benzo c phenanthrenes. J. Chem. Soc. Perkin Trans. 1 1997, 2903-2909.

85. Zhang, F.J.; Harvey, R.G. Efficient synthesis of the carcinogenic anti-diol epoxide metabolite of 5-methylchrysene. J. Org. Chem. 1998, 63, 2771-2773.

86. Meier, H.; Fetten, M.; Schnorpfeil, C. Synthesis of areno-condensed [24]annulenes. Eur. J. Org. Chem. 2001, 779-786.

87. Zhang, J.T.; Harvey, R.G. Syntheses of oxidized metabolites implicated as active forms of the highly potent carcinogenic hydrocarbon dibenzo def,p chrysene. Tetrahedron 1999, 55, 625-636.

88. Yang, C.X.; Harvey, R.G. Synthesis of methylene-bridged polycyclic aromatic hydrocarbons. $J$. Org. Chem. 1993, 58, 4155-4158.

89. Paudel, A.; Hu, J.Y.; Yamato, T. Synthesis and structural properties of novel polycyclic aromatic compounds using photo-induced cyclisation of 2,7-di-tert-butyl-4-(phenylethenyl)pyrenes. $J$. Chem. Res.-S 2008, 457-460.

90. Harvey, R.G.; Zhang, J.T.; Luna, E.; Pataki, J. Synthesis of benzo s picene and its putative carcinogenic trans-3,4-dihydrodiol and fjord region anti-diol epoxide metabolites. J. Org. Chem. 1998, 63, 6405-6408.

91. Blanco, O.; Castedo, L.; Cid, M.; Seijas, J.A.; Villaverde, C. N-Methylsecoglaucine, a new phenanthrene alkaloid from fumariaceae. Heterocycles 1990, 31, 1077-1080.

92. Castedo, L.; Granja, J.A.; Rodriguez de Lera, A.; Villaverde, M.C. Structure and synthesis of goudotianine, a new 7-methyldehydroaporphine from Guatteria goudotiana. J. Heterocycl. Chem. 1988, 25, 1561-1566.

93. Soicke, H.; Al-Hassan, G.; Frenzel, U.; Goerler, K. Photochemical synthesis of bulbocapnin. Arch. Pharm. 1988, 321, 149-152.

Appendix 1. Oxidative photocyclization, original conditions.

\begin{tabular}{|c|c|c|c|}
\hline Staring material & Conditions & Reference \\
\hline
\end{tabular}


Appendix 1. Cont.

\begin{tabular}{|c|c|c|c|}
\hline $\mathrm{Me}=\mathrm{Me}$ & $\begin{array}{c}0.5 \text { eq. } \mathrm{I}_{2}, \\
\text { Cyclohexane, } \\
\mathrm{h} v=24 \mathrm{~h} \\
(42 \mathrm{mmol} / \mathrm{L})\end{array}$ & ${ }_{\mathrm{MeMe}}$ & [52] \\
\hline$\underbrace{\mathrm{OMe}}_{\mathrm{OMe}}$ & $\begin{array}{l}\text { Cat. } \mathrm{I}_{2}, \\
\text { Ethanol, } \\
\text { hv }=8 \mathrm{~h}\end{array}$ & OMe & [53] \\
\hline$=\mathrm{OC}_{6} \mathrm{H}_{13}$ & $\begin{array}{c}0.67 \text { eq. } \mathrm{I}_{2}, \\
\text { Cyclohexane, } \\
\mathrm{hv}=47 \mathrm{~h}\end{array}$ & $\underbrace{\mathrm{Me}}_{\mathrm{OC}_{6} \mathrm{H}_{13} \quad 75 \%}$ & [54] \\
\hline $\mathrm{CO}_{2} \mathrm{Me}$ & $\begin{array}{c}0.3 \text { eq. } \mathrm{I}_{2}, \\
\text { Cyclohexane, } \\
\mathrm{h} v=?\end{array}$ & $75 \%$ & [51] \\
\hline$\sum_{\mathrm{CO}_{2} \mathrm{Me}}$ & $\begin{array}{l}\text { Cat. } \mathrm{I}_{2}, \\
\text { Toluene, } \\
\mathrm{h} v=24 \mathrm{~h}\end{array}$ & ${ }_{2} \mathrm{Me} 52 \%$ & [55] \\
\hline $\mathrm{CO}_{2} \mathrm{Et}$ & $\begin{array}{c}0.5 \text { eq. } \mathrm{I}_{2} \text {, Toluene, } \\
\mathrm{hv}=3 \text { days }\end{array}$ & ${ }_{\mathrm{CO}_{2} \mathrm{Et}}{ }_{49 \%}$ & [56] \\
\hline $\begin{array}{l}\text { yMe } \\
\text { OMe }\end{array}$ & $\begin{array}{l}\text { Cat. } \mathrm{I}_{2}, \\
\text { Methanol, } \\
\mathrm{h} v=30 \mathrm{~h}\end{array}$ & $\sum_{\mathrm{OMe} \quad 85 \%}^{\mathrm{CO}_{2} \mathrm{Me}}$ & [57] \\
\hline OMe & $\begin{array}{c}1 \text { eq. } \mathrm{I}_{2} \text {, Diethylether/ } \\
\text { DCM, } \\
\mathrm{h} v=?\end{array}$ & OMe $85 \%$ & [58] \\
\hline$\underbrace{}_{\mathrm{Me}}$ & $\begin{array}{c}\text { Cat. } \mathrm{I}_{2} \text {, Cyclohexane, } \\
\mathrm{hv}=7 \mathrm{~h}\end{array}$ & $\underbrace{\mathrm{Me}}_{\mathrm{Me}}=$ & [59] \\
\hline${ }_{\mathrm{Me}}^{\mathrm{Me}}$ & $\begin{array}{l}\text { Cat. } \mathrm{I}_{2} \text {, Cyclohexane, } \\
\qquad \mathrm{hv}=2 \mathrm{~h}\end{array}$ & ${ }_{\mathrm{Me}}^{\mathrm{Me}}$ & [59] \\
\hline
\end{tabular}


Appendix 1. Cont.

\begin{tabular}{|c|c|c|c|}
\hline $\mathrm{MeO}_{\mathrm{MeO}}^{-3}$ & $\begin{array}{l}\text { Cat. } \mathrm{I}_{2} \text {, Diethylether, } \\
\qquad \mathrm{h} v=3 \mathrm{~h}\end{array}$ & 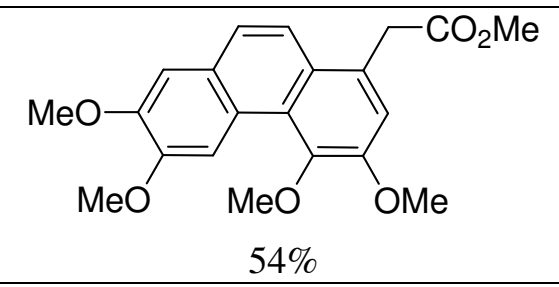 & [60] \\
\hline$\left.{ }_{\mathrm{MeO}}\right\rangle=\mathrm{MeO}_{\mathrm{OMe}}$ & $\begin{array}{l}\text { Cat. } \mathrm{I}_{2} \text {, Diethylether, } \\
\qquad \mathrm{h} v=3 \mathrm{~h}\end{array}$ & $\mathrm{MeO}_{40 \%} \mathrm{OMe}$ & [60] \\
\hline IN $\mathrm{HN}-\mathrm{CO}_{2} \mathrm{Et}$ & $\begin{array}{c}\text { Cat. } \mathrm{I}_{2} \text {, Diethylether/ } \\
\text { DCM, } \\
\mathrm{h} v=2 \mathrm{~h}\end{array}$ & 1) $80 \%$ & [57] \\
\hline $\mathrm{MeO}_{\mathrm{MeO}}^{\mathrm{PrO}}$ & $\begin{array}{l}\text { Cat. } \mathrm{I}_{2} \text {, Diethylether/ } \\
\text { DCM, } \\
\mathrm{h} v=5 \mathrm{~h}\end{array}$ & $\underset{\mathrm{MeO}}{\mathrm{MeO}}$ & [61] \\
\hline$={ }^{-\xi}=\mathrm{HN}_{\mathrm{Me}}^{\mathrm{O}}$ & $\begin{array}{l}\text { Cat. } \mathrm{I}_{2} \text {, Diethylether, } \\
\qquad \mathrm{h} v=2 \mathrm{~h}\end{array}$ & $=\longrightarrow{ }_{\mathrm{Me}}^{\mathrm{HN}-\mathrm{P}_{65 \%}}$ & [62] \\
\hline OMe & $\begin{array}{l}\text { Cat. } \mathrm{I}_{2} \text {, Cyclohexane, } \\
\qquad \mathrm{h} v=3 \mathrm{~h}\end{array}$ & OMe $60 \%$ & [63] \\
\hline 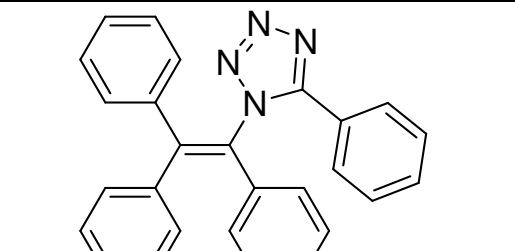 & $\begin{array}{c}\text { Cat. } \mathrm{I}_{2}, \\
\text { DCM/ } \\
\text { Cyclohexane, } \\
\text { hv }=1 \mathrm{~h}\end{array}$ & . & [64] \\
\hline $\mathrm{Me}$ & $\begin{array}{c}0.25 \text { eq. } \mathrm{I}_{2} \text {, Biacetyl, } \\
\text { Toluene, } \\
\text { hv }=40 \mathrm{~min} .\end{array}$ & & [65] \\
\hline & & $43 \%$ & \\
\hline
\end{tabular}


Appendix 1. Cont.

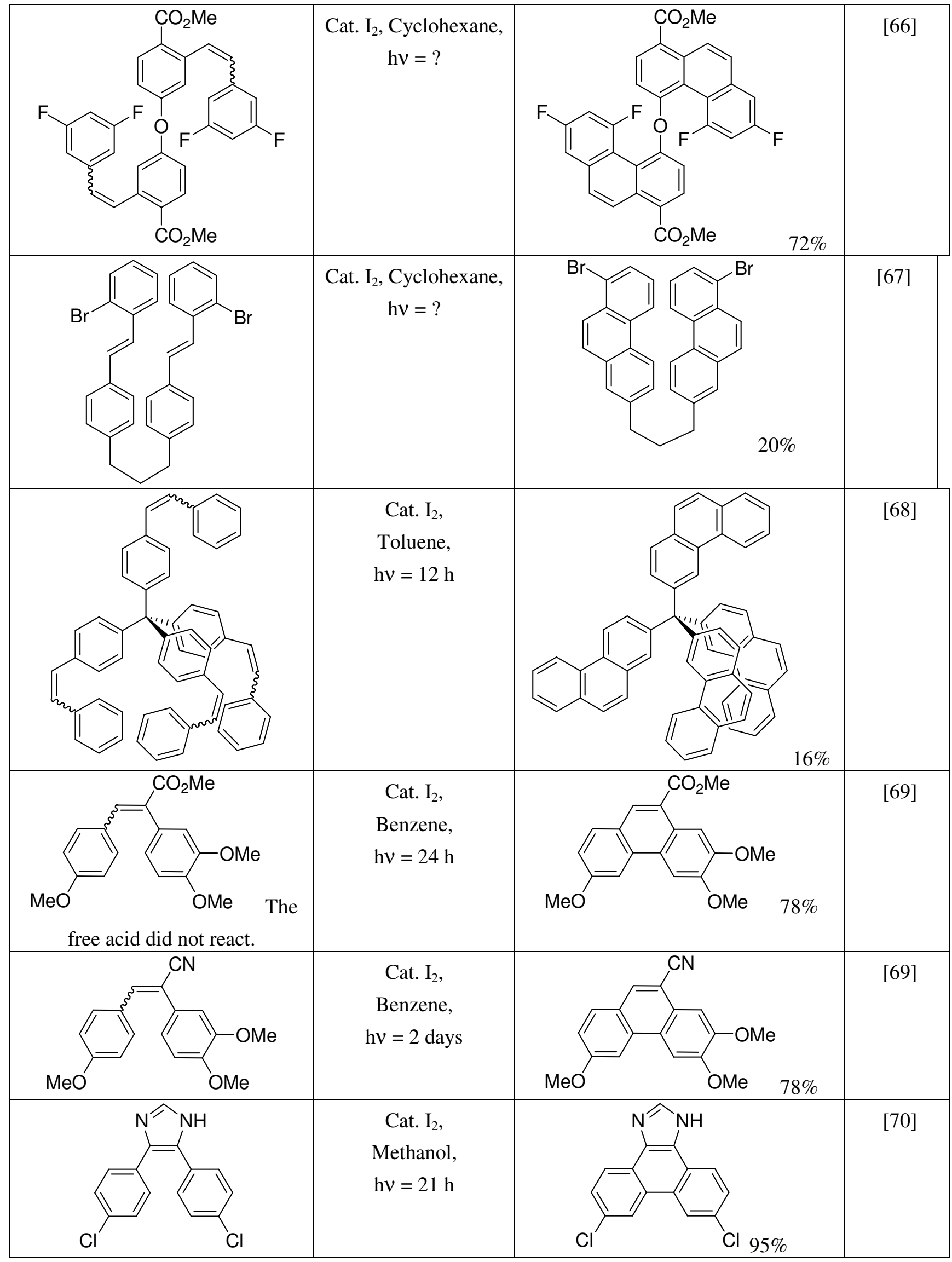


Appendix 1. Cont.

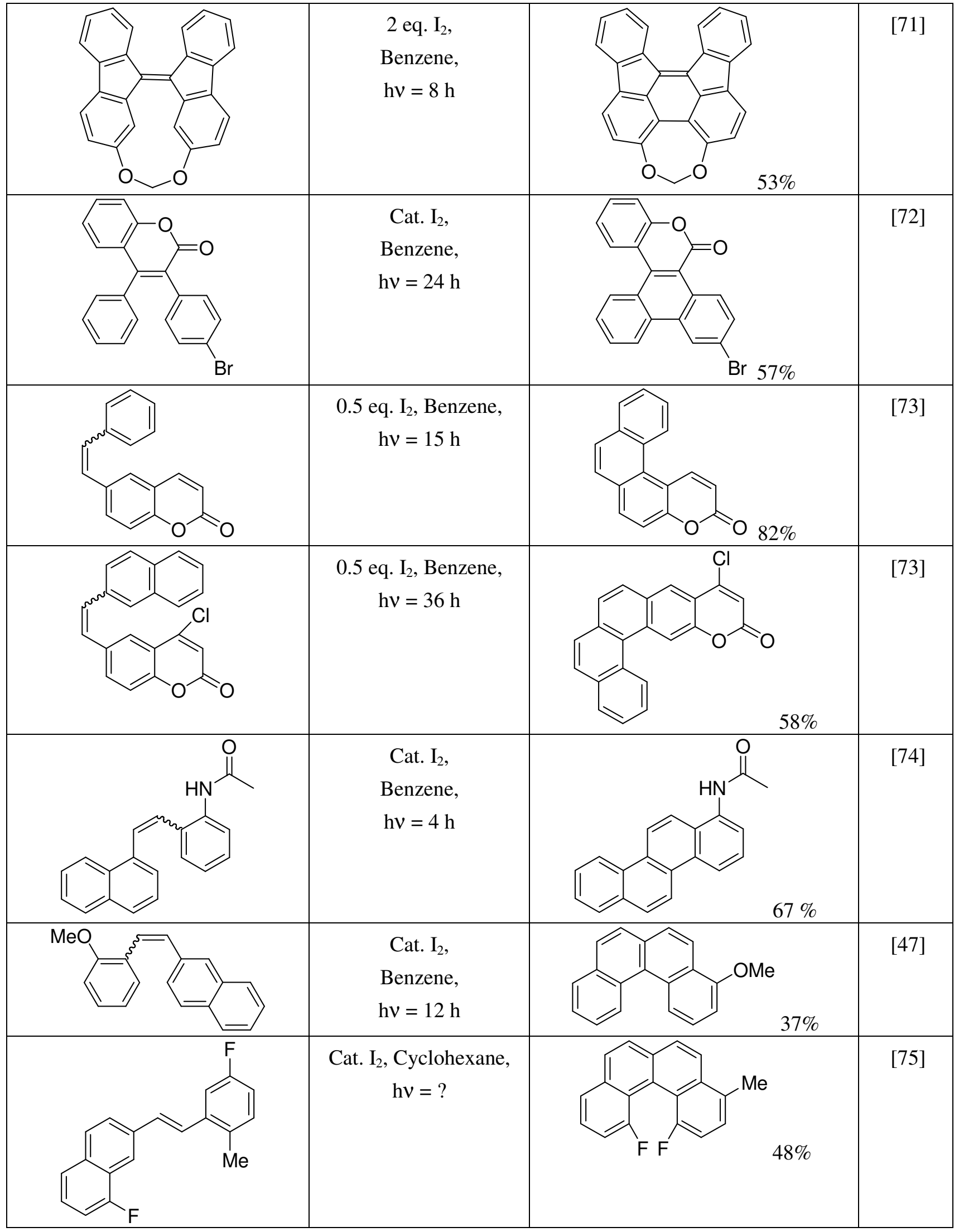


Appendix 1. Cont.

(1)

Appendix 2. Oxidative photocyclization, Katz's conditions.

\begin{tabular}{|c|c|c|c|}
\hline Staring material & Conditions & Peference \\
\hline
\end{tabular}


Appendix 2. Cont.

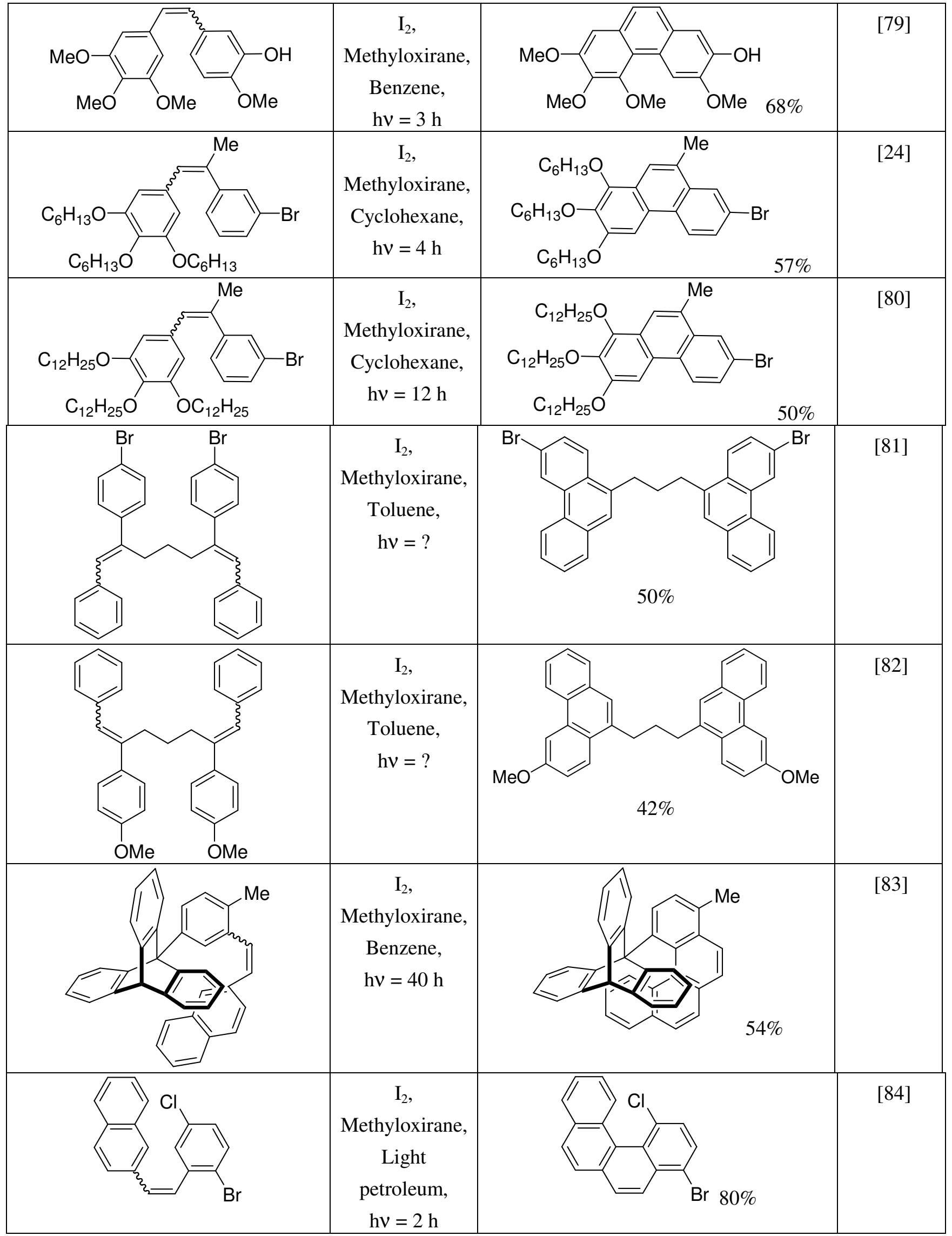


Appendix 2. Cont.

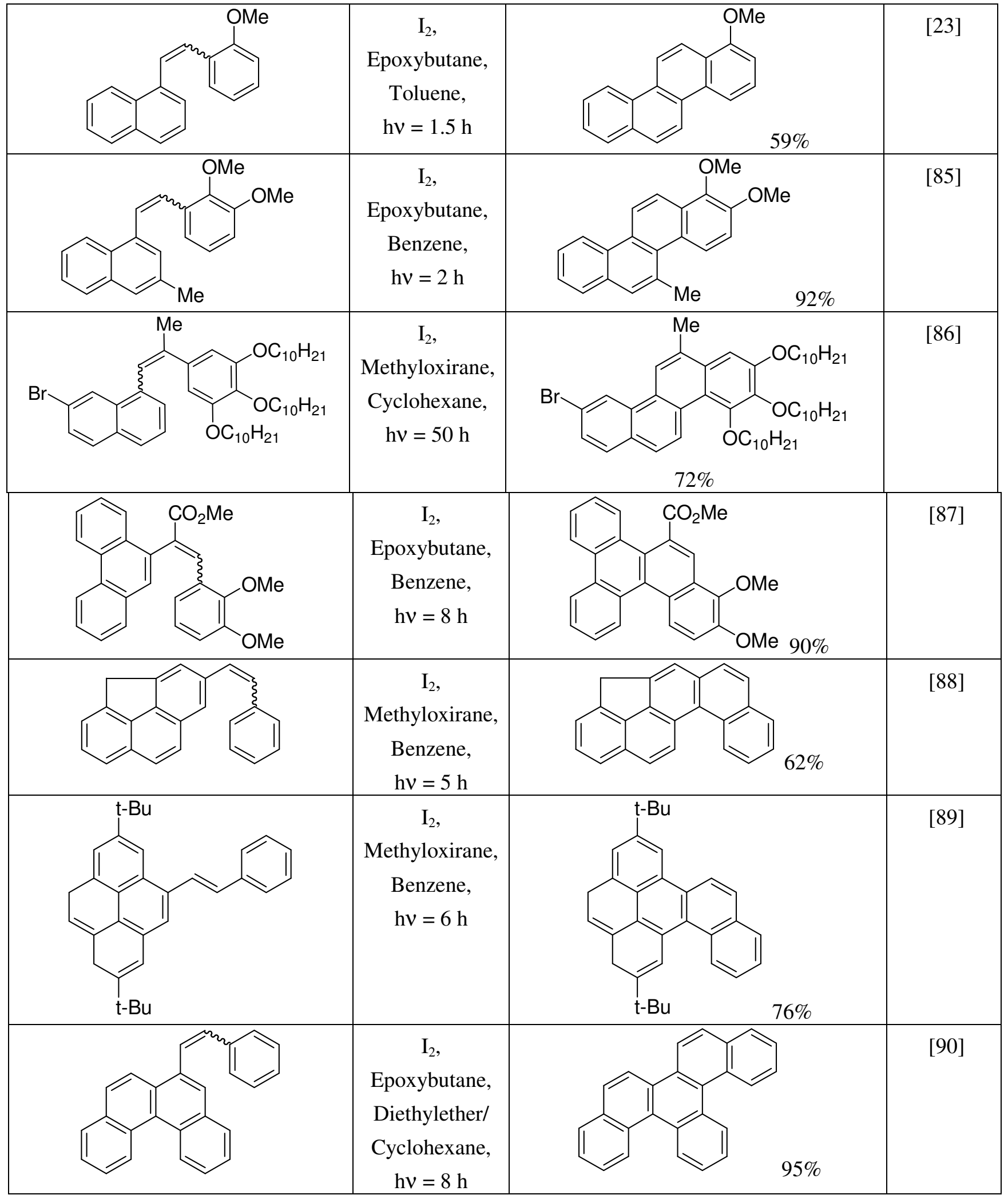


Appendix 2. Cont.

Methyloxirane,

Appendix 3. Elimination photocyclizations.

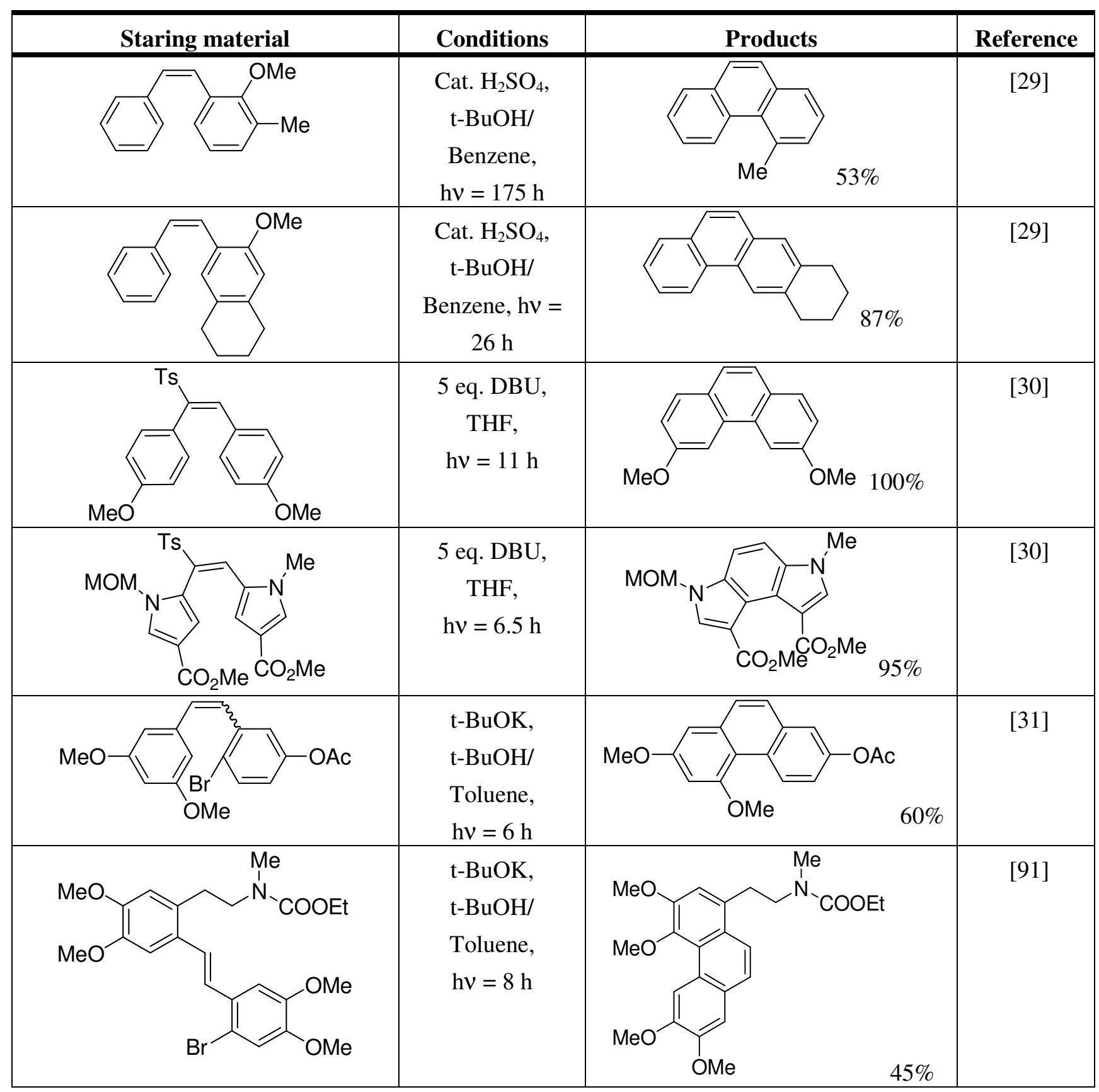


Appendix 3. Cont.



Sample Availability: Not available.

(C) 2010 by the authors; licensee MDPI, Basel, Switzerland. This article is an Open Access article distributed under the terms and conditions of the Creative Commons Attribution license (http://creativecommons.org/licenses/by/3.0/). 